Meta

Journal des tradlucteurs

Translators' Journal

\title{
Dryden's "Palamon and Arcite": Its Merits and Flaws as a Translation of Chaucer's "Knight's Tale"
}

Fred L. Milne

Volume 23, numéro 3, septembre 1978

URI : https://id.erudit.org/iderudit/003651ar

DOI : https://doi.org/10.7202/003651ar

Aller au sommaire du numéro

Éditeur(s)

Les Presses de l'Université de Montréal

ISSN

0026-0452 (imprimé)

1492-1421 (numérique)

Découvrir la revue

Citer cet article

Milne, F. L. (1978). Dryden's "Palamon and Arcite": Its Merits and Flaws as a

Translation of Chaucer's "Knight's Tale". Meta, 23(3), 200-210.

https://doi.org/10.7202/003651ar d'utilisation que vous pouvez consulter en ligne.

https://apropos.erudit.org/fr/usagers/politique-dutilisation/ 


\section{Dryden's «Palamon and Arcite» : Its Merits and Flaws as a Translation of Chaucer's «Knight's Tale»}

One means of evaluating Dryden's "Palamon and Arcite» as a valid translation of Chaucer's "The Knight's Tale" is through examination of the work in light of the principles of translation Dryden professed to follow. Although several studies have noted specific aspects of "Palamon and Arcite" in relation to Chaucer's original, the question of Dryden's adherence to his own professed principles as a translator has not been adequately addressed ${ }^{1}$. Certainly, those principles allowed Dryden considerable latitude, but they also imposed certain important restrictions. A comparative study of the translation and the original readily demonstrates significant alterations in narrative division, versification, motif and thematic emphasis, and character portrayal. Some of these changes are justified by the translator's guiding principles. But alterations in the "sense " or «spirit » of the original work not only violate an important principle adopted by Dryden, but also produce a work that is significantly different in meaning from the original.

In 1680, twenty years before publication of the Fables, Dryden formulated the method he would use in translating Chaucer. That method is paraphrase, "or translation with latitude, where the author is kept in view by the translator, so as never to be lost, but his words are not so strictly followed as his sense ; and that too admits to be amplified, but not altered ${ }^{2}$ ». The method makes no attempt to render a verbatim translation; rather, the translator attempts to conform his genius to that of the original author, " to give his thoughts either the same turn, if our tongue will bear it, or, if not, to vary the dress, not to alter or destroy the substance ${ }^{3} »$. Dryden was convinced that in translating by paraphrase « the spirit of an author may be transfused, and yet not lost ${ }^{4} »$. Because the translator is not attempting a « literal» translation, but only attempting to capture and preserve the spirit of the author, he is under no obligation to maintain the author's original mode of expression : «There... is a liberty to be allowed for the expression; neither is it necessary that words and dress be confined to the

1. Cf. William Frost, Dryden and the Art of Translation, New Haven, Yale University Press. 1955 ; Earl R. Miner, "Chaucer in Dryden's Fables". Studies in Criticism and Aesthetics, 1660-1800. Essays in Honor of Samuel Holt Monk, Minneapolis, University of Minnesota Press, 1967; and Robert D. Spector, «Dryden's Palamon and Arcite», Explicator, XI, Nov. 1952, item 7.

2. Essays of John Dryden, ed. W.P. Ker, New York, Russell and Russell, 1961, Vol, I, p. 237. References from Dryden's Essays are all from Ker's two-volume edition and will be cited as Essays.

3. Essays, I, 241

4. Essays, I, 241-242. 
measure of the original ${ }^{5}$." But, despite the latitude given the translator, the obligation to preserve the spirit of the original author demands that the translator use his latitude cautiously, because preservation of the spirit of the original author means that the sense of the original work must not be violated. Recognizing that obligation, Dryden explicitly says «the sense of an author, generally speaking, is to be sacred and inviolable ${ }^{6}$. The latitude given the translator is valid only in so far as it does not alter the sense of the original. It goes without saying that implicit in the statement is the supposition that the translator come to the original author objectively if he is to understand the sense of the work to be translated.

Biecause Dryden thought that Chaucer was « a rough diamond " which « must first be polished ere he shine ${ }^{7}$ 》 and that his language was " so obsolete that his sense is scarce to be understood ${ }^{8}$," the paraphrase method of translation was most appropriate. If scrupulously followed, the method would allow Dryden ample opportunity to polish the work and at the same time rescue the sense from its obsolete language. The remainder of this study will examine Dryden's "Palamon and Arcite" to determine what alterations were made in polishing the work and to see if the sense is preserved.

The most obvious alteration effected by Dryden may be observed in narrative division. Dryden fashioned his translation into three divisions to Chaucer's four. The three-part division effects a significant realignment of the narrative by which « Dryden is better able to group his material according to unity of time and action, and to center it around the main action of each book ${ }^{9} m$. In Chaucer's tale, the first division develops the rivalry between Palamon and Arcite and ends with Arcite's release from prison and his banishment from Athens. Dryden extends his first division to include Arcite's secret return to Athens. The extension integrates the whole of the first part of Arcite's adventure, keeps the main action centered in Athens, and allows the second division to open with attention on Palamon ${ }^{10}$. Chaucer's second division ends with Palamon and Arcite returning to Thebes to collect their knights for the tournament. Dryden extends his second division to include the building of the amphitheater and temples in preparation for the tournament. The extension allows Dryden to effect a division corresponding to a time-lapse in the narrative action and to concentrate in a single, final division all the immediate circumstances of the tournament. Chaucer, on the other hand, divides these circumstances between his third and fourth divisions. The striking unity of effect produced by the concentration of related events in one rather than two divisions is a masterful technical improvement over the original.

Earl Miner has pointed out that Dryden's three-part division gives a much clearer narrative than Chaucer's, because Dryden's story may be sharply divided into a beginning, a middle, and an end "1. But there is no indication that Dryden's division is

Essays, I, 242.

6. Essays, I, 242.

7. Essays, II, 265.

8. Essays, II, 265.

9. Robert D. Spector, «Dryden's Palamon and Arcite", Explicator, XI, Nov. 1952, item 7.

10. Earl Miner, "Chaucer in Dryden's Fables". Studies in Criticism and Aesthetics, 1660-1800: Essays in Honor of Samuel Holt Monk, Minneapolis, University of Minnesota Press, 1967, p. 68.

11. Ibid., p. 68 . 
in any way artificial. He was not merely adhering to Aristotle's classical formula and imposing it on Chaucer. The narrative line in Dryden is clearer because he makes explicit in his narrative division a natural, three-part division implicit in the original tale. The conflict between Palamon and Arcite is initiated, intensified, and resolved in theree altercations : the first in prison, the second in the grove, and the third at the tournament. By fashioning each of his divisions around one of the three altercations, Dryden reflects in his external structure the natural division of the narrative line and effects a relationship between the two which is missing in Chaucer.

Besides altering the narrative division, Dryden significantly altered the versification than is found in Chaucer. Chaucer used the rhymed couplet in «The Kinght's Tale, " but the relation between the couplet as a frame or receptacle and the idea it embraces is often loose; many times the ideas cut across couplet-boundaries. Dryden, on the other hand, used the closed couplet whenever possible so that the idea might be enclosed by a single rhyme pattern. Several comparative examples may best illustrate the point :

Ther maistow seen, comynge with Palamon

Lygurge hymself, the grete kyng of Thrace.

$$
\text { (A } 2128-2129)^{12}
$$

With Palamon, above the rest in place,

Lycurgus came, the surly King of Thrace.

$$
\text { (III, 38-39) }{ }^{13}
$$

Myn is the drenchyng in the see so wan;

Myn is the prison in the derke cote...

(A 2456-2457)

Mine is the shipwreck in a Wat'ry sign;

And in an Earthy, the dark Dungeon mine.

(III, 401-402)

But yet hadde I foryeten to devyse

The noble kervyng and the portreitures,

The shap, the contenaunce, and the figures,

That weren in thise oratories thre.

Within these Oratories might you see

(A 1914-1917)

Rich Carvings, Pourtraitures, and Imagery:

Where ev'ry Figure to the Life express'd

The Godhead's Pow'r to whom it was address'd.

$$
\text { (II, 467-470) }
$$

In each example Chaucer has cut across couplets to express his idea, whereas Dryden has not. The ideas expressed by Chaucer in the first and second examples cut across the last line of one couplet and the first line of another. Dryden expressed the same ideas in a single closed couplet each. In the third example, Chaucer expressed his idea in four lines. Although the first line begins a new paragraph, it is actually the last line of a couplet whose first line concludes the preceding paragraph. The second and third lines do constitute a complete couplet, but they do not express a complete idea. The

12. The Works of Geoffrey Chaucer, ed. F.N. Robinson, 2nd. edition, Boston, Houghton Mifflin, 1957. All citations of Chaucer's work refer to Robinson's second edition.

13. The Poems of John Dryden, ed. James Kingsley, Oxford, The Clarendon Press, 1958, Vol. IV. All citations of Dryden's poetry refer to Vol. IV of Kingsley's edition. 
fourth line, which completes the idea, is another half-couplet. Turning to Dryden's translation of the same idea, we see that he uses two complete couplets and shapes the idea in such a way that it falls into two parts, each part enclosed by a couplet. In each example, the relationship between versification and idea is tighter in Dryden's translation than in Chaucer's original.

Dryden's insistence on a tight relationship between versification and idea led him to introduce variety in versification not found in Chaucer. Although Chaucer used only the rhymed couplet, Dryden did not hesitate to introduce a triplet whenever he thought it useful. The triplet served the same purpose as the closed couplet, i.e. it allowed an important idea to be expressed in a single rhyme pattern. Examine the following comparative example :

For trusteth wel that dukes, erles, kynges

Were gadered in this noble compaignye,

For love and for encrees of chivalrye.

$$
\text { (A 2182-2184) }
$$

For Kings, and Dukes, and Barons you might see, Like sparkling Stars, though diff'rent in Degree,

All for th' Increase of Arms, and Love of Chivalry.

$$
\text { (III, 94-96) }
$$

Chaucer expressed his idea by using a couplet fragment in 1.2182 and one complete couplet (11,2183-2184). Dryden, on the other hand, used the triplet to enclose the complete idea in a single rhyme pattern and maintained the same tight relationship between versification and idea effected by the closed couplet.

Dryden often used versification to compress or expand whatever he found in the original to be either verbose or redundant, on the one hand, or insufficiently amplified, on the other. In the following example notice the compression effected by the translation of Chaucer's four lines in only three :

O Cupide, out of alle charitee !

$O$ regne, that wolt no felawe have with thee!

Ful sooth is seyd that love ne lordshipe.

Wol noght, his thankes, have no felaweshipe.

$$
\text { (A } 1623-1626
$$

O Love! Thou sternly dost thy Pow'r maintain,

And wilt not bear a Rival in thy Reign :

$T$ yrants and thou all Fellowship disdain.

$$
\text { (II, 166-168) }
$$

The triplet is used to compress what William Frost calls the "garrulity of the original ${ }^{14} »$. Occasionally, Dryden both compresses and expands in the same passage, as in the following example :

"Heere cometh my mortal enemy!

Withoute faille, he moot be deed, or I;

For outher I moot sleen hym at the gappe,

Or he moot sleen me, if that me myshappe" -,

14. Dryden and the Art of Translation, New Haven, Yale University Press, 1955, p. 54. 
So ferden they in chaungyng of hir hewe,

As fer as everich of hem oother knewe.

Here comes my mortal Enemy,

(A 1643-1648)

And either he must fall in Fight, or I :

This while he thinks, he lifts aloft his Dart;

A gen'rous Chilness seizes ev'ry Part;

The Veins pour back the Blood, and fortifie the Heart.

(II, 185-189)

Dryden's translation compresses the dialogue, but expands the narrative comment. By compressing Chaucer's four lines of dialogue (two complete couplets) into two lines (a single couplet), Dryden eliminates verbosity. More striking is the expansion of the narrative comment from a couplet to a triplet. The expanded comment heightens the dramatic effect of the moment by emphasizing the tense physical alertness of the knights as they approach each other for combat. The passage is a fine example of Dryden's skillful management of compression and expansion by means of versification and of his dramatic sense in narrative.

In addition to alterations in narrative division and versification, Dryden used the latitude allowed by his method to reinforce motifs and thematic emphasis. For example, he significantly reinforces the three motif. We have already seen that Dryden chose to fashion his narrative divisions around the three altercations between Palamon and Arcite. In so doing he reflected not only a division natural to the narrative line, but also one of the dominant motifs running through the tale. Chaucer repeatedly used the three motif. In addition to the three altercations, Palamon, Arcite, and Emily are the three parties to a love triangle. There are three patron gods, three temples, and three propitiations offered at three different hours before the tournament. The three motif is prominent in Arcite's funeral ceremonies. Dryden seized on the motif and extended its use beyond what he found in the original. For example, Dryden has Arcite serve three years in Athens before his confrontation with Palamon in the grove (III, 607), whereas Chaucer merely says that Arcite had been in Athens « $A$ yeer or two" (A 1426). Dryden introduces the motif in describing the festivities sponsored by Theseus as running "thrice three days" (III, 732) after the tournament. The motif is again introduced in Theseus' final speech, in which a reference to the tripartite composition of the human soul is inserted :

Retchless of Laws, affects to rule alone,

Anxious to reign, and restless on the Throne:

First vegetive, then feels, and reasons last;

Rich of Three Souls, and lives all three to waste.

$$
\text { (III, 1074-1077) }
$$

No such reference is found in the original. Finally, Dryden extends use of the motif beyond Chaucer's in describing Arcite's funeral ceremonies :

Ne how the Grekes, with an huge route,

Thries riden al the fyr aboute

Upon the left hand, with a loud shoutynge,

And thries with hir speres claterynge;

And thries how the ladyes gonne crye...

(A 2951-2955)

Then thrice the mounted Squadron ride around

The Fire, and Arcite's Name they thrice resound: 
Hail, and Farewell, they shouted thrice amain,

Thrice facing the Left, and thrice they turn'd again:

Still as they turn'd, they beat their clatt'ring Shields.

$$
\text { (III, 992-996) }
$$

In five lines Dryden uses the motif five times to Chaucer's three. By extending the three motif, Dryden emphasizes the relationship between the internal and external elements of the translation.

To reinforce thematic emphasis in his translation, Dryden extends another motif : the rose, a traditional symbol of love and the flower of Venus, goddess of love ${ }^{15}$. Chaucer used the motif once, in association with Emily (A 1038), but he made no further use of it despite the tradition which would have made it an appropriate motif to emphasize. Dryden, on the other hand, used the motif several times in its traditional association with love. He incorporated the motif into his description of the statue of Venus, on whose head was seen "A wreath of Roses Red» (II, 518). He furthers the rose-Emily association suggested by Chaucer and inserts a new passage in his translation which comes shortly after the initial association is made :

At ev'ry Turn, she made a little Stand,

And thrust among the Thorns her Lilly Hand

To draw the Rose, and ev'ry Rose she drew,

She shook the Stalk, and brush'd away the dew ${ }^{16}$.

$$
\text { (I, 191-194) }
$$

Dryden's use of the rose-Emily association foreshadows Emily's capacity to draw love to herself, for just as Emily draws the rose, she will draw the love of Palamon and Arcite. Finally, Dryden introduces the rose motif in the grove scene. When Arcite goes to the grove to sing praises of May, his love for Emily is renewed in intensity. Foreshadowing that renewal, Dryden inserts the narrative comment that the sun " with his tepid Rays the Rose renews» (II, 41). Symbolically, through the rose motif, Dryden reinforces the love theme in his translation.

Several times Dryden reinforces the love theme directly as well as symbolically. Lest the reader lose sight of the love motive in the midst of the furious combat between Palamon and Arcite in the grove, Dryden inserts a direct but subtle reminder :

Fell Arcite like an angry Tyger far'd

And like a Lion Palamon appear'd :

Or as two Boars whom Love to Battel draws,

With rising Bristles, and with froathy Jaws,

Their adverse Breasts with Tusks oblique they wound.

$$
\text { (II, 202-206) }
$$

The original passage is basically the same, but the thematic reminder in Dryden's third and fifth lines is missing in the original :

15. George Ferguson, Signs and Symbols of Christian Art, New York, Oxford University Press, 1966, p. 37 .

16. The passage masterfully contrasts two aspects of Emily's character: her purity (signified by the lily hands) and her capacity to evoke love (signified by drawing the rose to herself). Thus, Dryden uses two flower motifs in the passage and draws on the traditional symbolism of both. Cf. Ferguson, p. 33, for the lily symbolism. 
Thou myghtest wene that this Palamon

In his fightyng were a wood leon,

And as a crueel tigre was Arcite;

As wilde bores gonne they to smyte

That frothen with as foom for ire wood.

(A 1655-1659)

The reader of "Palamon and Arcite " is again reminded of the love motive as the two knights leave the grove for Thebes to prepare for the tournament. In Chaucer the rivals ride off immediately after Theseus proposes the tournament; no mention is made of Emily at that moment :

And thus with good hope and with herte blithe

They taken hir leve, and homeward gonne they ride

To Thebes, with his olde walles wyde.

$$
\text { (A 1878-1880) }
$$

Dryden thought it necessary to emphasize the love motive and Emily's role in the conflict :

The Knights with Leave

Departing from the Place, his last commands receive;

On Emily with equal Ardour look,

And from her Eyes their Inspiration took.

From thence to Thebes old Walls pursue their Way,

Each to provide his Champions for the Day.

$$
\text { (II, 430-435) }
$$

A final example should illustrate the subtlety with which Dryden emphasized the love theme. In describing the temple of Mars, Chaucer used the following couplet :

Depeynted was the slaughtre of Julius,

Of grete Nero, and of Antonius.

$$
\text { (A 2031-2032) }
$$

Now compare the expanded passage in Dryden :

There saw I Mars in his Ides, the Capitol,

The Seer in vain foretelling Caesar's Fall,

The last Triumvirs, and the Wars they move,

And Antony, who lost the World for Love.

$$
\text { (II, 604-607) }
$$

Dryden heightened the foreboding of Arcite's fall (the temple described was built to Arcite's patron god), but more importantly, the love motive is introduced with Anthony and by analogy with Arcite. We see that Dryden chose to emphasize the love motive more than Chaucer. The extended emphasis forges a tighter internal unity, but in no way does it alter the sense of the original.

Although none of the alterations examined thus far significantly changes the sense of the original, there remains another which must be considered, namely, the introduction of what has been called a "new motive - remorse of conscience ${ }^{17}$ " for Arcite. The new motive required a significant shift in characterization which must be

17. John Wilson, «Dryden and Chaucer», Blackwoods Magazine, LVII, 1845, p. 781. 
carefully examined. In the original tale, Palamon and Arcite are characterized with marked impartiality. There is no suggestion that either knight is morally superior to the other. As Earl Miner points out, both knights seem «almost to be equally good men led into trouble by amourousness and wrath $18 \mathrm{~m}$. Both are equally strong and equally well-versed in chivalry. Their characters are differentiated only by their contrasting response to Emily: Palamon's love is spiritual (he sees Emily as a goddess and loves her as such), whereas Arcite's love is physical. Their contrasting response in love reflects a basic thematic conflict between love that is spiritual and enduring and love that is physical and transitory. But Chaucer avoids overt partiality in both characterization and thematic development by having fate determine the conflict. Palamon's ultimate victory over Arcite does not suggest he is the better man; his victory is not a victory of moral superiority. That the man who sought the spiritual and enduring wins in the end is only because fate has decreed it so. Chaucer's emphasis on the role of fate makes any moral differentiation between Palamon and Arcite irrelevant. Had he discriminated between the knights, suggesting that one was better than the other, he would have undermined the role of fate. The only way he could emphasize fate as determining the rivalry between the knights was by characterizing the two impartially.

Dryden, on the other hand, treats Arcite pejoratively because he chose to make the question of Arcite's disloyalty to Palamon - a question Chaucer kept peripheral- central to his characterization. Emphasis on the question of disloyalty forced a shift in characterization and led to the introduction of the new motive. The alteration effected by Dryden injects a moral tone into the narrative which Chaucer did not intend.

Arcite's initial reaction to Emily in Dryden's translation is different from that in Chaucer's original and provides the first evidence that a shift in characterization has been effected. In Chaucer, Arcite's initial reaction to Emily merely foreshadows his fate : "The fresshe beautee sleeth me sodeynly" (A 1118). Dryden expands the reaction and inserts a subtle insinuation which reflects on Arcite's character :

The Beauty I behold has struck me dead:

Unknowingly she strikes; and kills by chance;

Poyson is in her Eyes, and Death in ev'ry Glance.

$$
\text { (I, 277-279) }
$$

The poison reference suggests the corrupting influence which love has on Arcite. Immediately his friendship with Palamon is poisoned and his sense of personal loyalty abandoned. From this point on, Dryden's translation depicts Arcite as the corrupted knight. Not only is he Palamon's inferior, but his love is inferior as well because it is corrupting.

Having inserted poison as a symbol of Arcite's disloyalty, Dryden continues to emphasize the question of loyalty throughout his translation. In the grove, Dryden has Palamon make two specific references to the question not found in Chaucer. The first occurs when Arcite offers to give Palamon a fair fight : « His Promise Palamon accepts : But pray'd,/ To keep it better than the first he made" (II, 162-163). The

18. Miner, op. cit., p. 69. 
second occurs when Palamon addresses Theseus and identifies himself and Arcite. Loyalty is the theme of his address :

Arcite of Thebes is he; thy mortal foe,

On whom thy Grace did Liberty bestow,

But first contracted, that if ever found

By Day or Night upon th' Athenian Ground,

His Head should pay the forfeit: See return'd

The perjur'd Knight, his Oath and Honor scorn'd.

For this is he, who with a borrow'd Name

And profer'd Service, to thy Palace came,

Now call'd Philostratus: retain'd by thee,

A Traytor trusted, and in high Degree,

Aspiring to the Bed of beauteous Emily.

My part remains: From Thebes my Birth I own,

And call myself the unhappy Palamon.

Think me not like that Man; since no Disgrace

Can force me to renounce the Honor of my Race.

Know me for what I am: I broke thy Chain,

Nor promis'd I thy Pris'ner to remain:

The love of Liberty with Life is giv'n,

And Life it self th' inferior Gift of Heaven.

Thus without crime I fled...

$$
\text { (II, 276-293) }
$$

The corresponding passage in Chaucer runs only eleven lines (A 1724-1735) to Dryden's seventeen. The essential difference is the contrast which centers on loyalty in Dryden's translation. Arcite has been disloyal not only to Palamon, but also to Theseus, to his native city, and to his own name. Such epithets as "perjur'd Knight" and "Traytor trusted" make Arcite the villain. When compared to Palamon's forthright honesty and firm refusal to compromise honor and loyalty, Arcite's actions are made to seem reprehensible. The sharp character delineation introduced in the grove scene sets the stage for Arcite's death-bed speech in Dryden's translation. It is there that we see how far Dryden has gone in recasting Arcite's characterization and motivation.

A comparative reading of the death-bed speech in Chaucer and in Dryden reveals significant differences in the translation that go far beyond paraphrase. In Chaucer's version, Arcite dies recognizing that fate has defeated him :

"What is this world? what asketh men to have?

Now with his love, now in his colde grave

Allone, withouten any compaignye.

Fare wel, my sweete foo, myn Emelye !

And softe taak me in youre armes tweye,

For love of God, and herkneth what I seye.

I have heer with my cosyn Palamon

Had strif and rancour many a day agon

For love of yow, and for my jalousye."

(A 2777-2785)

The emphasis is on fate. The admission that jealousy motivated the conflict implies no wrong-doing on Arcite's part, but rather that the jealousy was inevitable. Now read Dryden's version of the same speech : 
Ah ! my sweet Foe, for you, and you alone,

I broke my Faith with injur'd Palamon.

But Love the sense of Right and Wrong confounds,

Strong Love and proud Ambition have no bounds.

And much I doubt, shou'd Heav'n my Life prolong,

I shou'd return to justify my Wrong:

For while my former Flames remain within,

Repentenance is but want of Pow'r to sin.

With mortal Hatred I pursu'd his Life,

Nor he, nor you, were guilty of the Strife,

Nor I, but as I lov'd: Yet all combin'd.

Your Beauty, and my Impotence of Mind;

And his concurrent Flame, that blew my Fire;

For still our Kindred Souls had one Desire.

(III, 806-819)

There is no suggestion that fate has defeated Arcite. He has defeated himself in being faithless to Palamon and wrong in his love. Arcite confirms his own villainy in a moment of remorse, but a tinge of villainy remains to the end because Arcite's remorse is offered begrudgingly : "Repentance is but want of Pow'r to $\sin$ ".

After Arcite's death-bed speech in Dryden's translation, there is no doubt that he has imposed a moral distinction in his characterization and thereby altered Chaucer's intended sense. The distinction makes Arcite Palamon's moral inferior and suggests that he was defeated because of that moral inferiority. The suggestion seriously diminishes the role of fate which Chaucer intended, without regard to the merits of the contending Thebans, to be the sole arbiter of the conflict. The shift from fate to character motivation as the resolution of the conflict renders an entirely different sense from that of the original.

Apparently Dryden did not intentionally alter Chaucer's sense but merely thought he was amplifying a moral distinction implied in Chaucer's characterization of Arcite. In his Preface to the Fables Dryden says that Chaucer «makes Arcite violent in his love, and unjust in his pursuit of it: Yet when he came to die, he made him think more reasonably : He repents not of his Love, for that had altered his Character ; but acknowledges the Injustice of his Proceedings, and resigns Emilia to Palamon 19, " If Dryden's reading is correct, then the explicit repentance in the translation would merely amplify Chaucer's sense where Dryden felt it was not sufficiently expressed. There would be no violation of Chaucer's intention. But we have seen that Chaucer does not in fact have Arcite repent on his death-bed. There is no suggestion of wrongdoing in the original. On the contrary, Arcite goes out of his way to be fair with Palamon. If he were the villain Dryden depicts, why did he not kill Palamon when he discovered him unarmed in the grove? Was it not because Arcite's nobility compelled him to deal fairly with his foe? And does not Chaucer exonerate Arcite's apparent disloyalty to Palamon by emphasizing that love knows no "positif lawe» (A 1167)? All the evidence in the original tends to discredit Dryden's reading and leads to the conclusion that Dryden himself must have read the moral judgment against Arcite into the original.

19. Essays, II, 257. 
There is evidence to support the supposition that Dryden came to Chaucer with a moral predisposition. Dryden says in the Preface to the Fables that he chose to translate only those tales by Chaucer " as savour nothing of immodesty 20 ». Such a statement implies a moral predisposition in Dryden's approach to Chaucer. He did not come to Chaucer objectively but subjectively, and his subjectivity found subsequent expression in his translation of «The Knight's Tale ». Failure to approach Chaucer on his own grounds destroyed the objectivity with which any translator must approach the original if he is to understand and translate unaltered the intended sense of the work. Because he lacked that objectivity, Dryden unconsciously violated not only Chaucer's sense, but also the primary objective set forth in his method of translation, i.e., preservation of the sense of the original ${ }^{21}$.

The evidence presented in the foregoing study makes it clear that Dryden's translation of «The Knight's Tale » significantly alters the original. We have seen that he used the latitude afforded by his method to alter the narrative division, versification, and motif and thematic emphasis. None of these alterations affects the sense of the original. Taken collectively, they demonstrate Dryden's technical and artistic skill, and in this respect his translation excels the original. But the shift in Arcite's character portrayal and motivation seriously alters the sense of the original and violates the primary restriction imposed on the translator by his own method and theory of translation. Although the alteration appears to have been caused by an unintentional misreading of Chaucer, it does reflect a basic lack of the objectivity desirable in any translator. Because he brought a subjective moral predisposition to his reading of Chaucer which subsequently found expression in his translation, Dryden failed to preserve Chaucer's sense in «Palamon and Arcite ». Thus, despite its technical and artistic brilliance, Dryden's translation is a failure in terms of the method used in making the translation.

FRED L. MILNE

20. Essal's, II, 263.

21. In Dryden and the Art of Translation, William Frost suggests that Dryden's moral reading may have been conscious : "All the evidence... seems to me to suggest that Dryden, like Milton writing Samson Agonistes in his old age, projected into symbolic situations of poetry emotions arising out of his own position in life and out of what he took to be the deteriorating political situation around him ..." Frost goes on to point out that for Dryden «Arcite becomes a symbol of military success vitiated by personal disloyalty (William III was an able soldier, and had ousted his predecessor, James, with little trouble) while Palamon represented loyal failure eventually rewarded by divine intervention " (p. 76). If you accept Frost's position, then you -must call into question Dryden's integrity as a translator because conscious alteration of the sense of the original exhibits an intentional infidelity to the method Dryden professed to follow. I do not believe Dryden's integrity would have allowed him to violate consciously his purpose in translating Chaucer. 